\title{
LOYALTY BEYOND SEASONS
}

\section{Temporal reproductive isolation in Homo sapiens.}

\section{BY MOHSEN H. DARABI}

$\mathrm{I}$ started to have feelings for her in the October. We were in the same class. I presented her with a red rose in an attempt to express my love for her, but she refused to accept it. A month later, I asked my aunt to talk to her after class on my behalf. That didn't go well either. "I'm busy with my courses," she told my aunt. "I won't have much time for other matters."

As the climate got colder, my feelings for her began to fade away. As December turned into the January of a new year, I often found myself thinking that the very idea of a relationship with her was ridiculous. But spring came, and with it a rise in temperature. She started to stare at me in class. Sometimes she smiled at me and blushed. It was in April that she finally came up to me. "Let's have lunch together," she said. "I will be in the dining hall at 12:30."

I agreed to meet her, but in my heart I was not keen - my instinct told me that she wasn't for me, so I skipped the date and ate lunch alone. She remained persistent in her desire, but I had lost my affection for her. She sent me a message reminding me of my attentions in the previous autumn. She mentioned the red rose and my aunt. But try as I might, I couldn't get excited about being with her any more. The season had changed.

Spring turned into summer. Her feelings towards me lessened slowly from about June onwards, but I thought that she still liked me. Autumn came, taking summer's heat. To my surprise, I began loving her again - exactly as I had the year before. This time, I decided to see her father and ask for his daughter's hand in marriage. Finding his address was a problem. I was ashamed to ask her for it directly, given that I had spurned her attentions back in the spring. I found it, eventually, and I met him that November.

"It depends on my daughter's opinion," her father said. "If she agrees, I will have no objection."

"Might I call you tomorrow to know her answer?" I asked.

"No, I'll call you myself and let you know," he insisted. I had no choice but to agree.

He didn't call. Eleven days elapsed - there was still no sign of his number on my phone. I finally decided to talk to her directly. I don't want to go into everything she told me then, but, in summary, she had lost interest in me. I remembered the rose, and how she had refused it. I remembered my aunt's unsuccessful intervention.

you will excuse me..."

"No Mohsen, wait -" she interrupted. "I made a mistake in refusing you. Forget about the past. Let's be friends now."

"I'm afraid I can't, not any more," I said. "I’m sorry." I walked away but her next words brought me to a dead stop.

"But you spoke to my father," she pleaded, "and even before that you wanted me, isn't that true?" I turned and saw tears in her eyes for the first time. Slowly but eagerly, she stepped closer and very faintly, she said: "Kiss me, Mohsen. I'm home." I dived into the pacific depths of her desperate heart and, although I wasn't attracted to her at that time of the year, I decided to kiss her.

I decided to, not because I was attracted to her, but because I am a human. I can think and remember things. I remembered how I had felt about her each autumn. She was certainly feeling the same about me each spring. I kissed her quivering lip because I cared about her and didn't want to see her upset. On my part, this had nothing to do with physiological love. Commitment following conscious thought is a characteristic of human behaviour.

As we kissed, I cursed Mother Nature for programming our mating seasons differently. I was cursing because seasonal changes altered our hormonal

With a heavy heart, I walked away.

The year turned. Winter came once again, and spring followed. In April, she started looking at me lustfully again, just as she had the year before. I became frustrated, and then angry, as it was now obvious that I had no sense of romance in me at that time of the year and she was exactly the opposite.

She confronted me when I was alone, somewhere quiet, but was too embarrassed to say anything more than: "Hello."

I broke the awkward silence with polite formalities: I asked how her father was, or some such. She looked into my eyes and smiled. "He's fine and he sometimes asks me $\rightarrow$ NATURE.COM

Follow Futures on

Facebook at:

go.nature.com/mtoodm how you're doing."

"Please tell him I'm well and that I send him my best regards," I replied, stuffily. "Now if balances in different ways.

The fact is that she gets passionate about me when temperatures rise in spring, but I am attracted to her when temperatures fall in autumn. This means that we will never feel passionate about each other simultaneously. But as two humans, we have the potential to think about these facts and respect each other's physiologies. This is when true love shows itself; when two people love each other by understanding and respecting each other.

By the autumn of 2011, she too had become aware of these concepts and promised to care about me likewise.

It is now 7 December 2011. So far, our commitment lives on.

Mohsen H. Darabi is a 21-year-old male human. He dreams of establishing a reindeer farm in Persia and a camel farm in Sweden. 